\title{
Influence of temperature, humidity and rainfall on field population trend of Stomoxys calcitrans (Diptera: Muscidae) in a semiarid climate in Mexico
}

\author{
CARLOS CRUZ-VÁZQUEZ*, IRENE VITELA MENDOZA*, MIGUEL RAMOS PARRA*, \\ and ZEFERINO GARCÍA-VÁZQUEZ**
}

\begin{abstract}
The influence of temperature, humidity and rainfall on field population trend of stable fly, Stomoxys calcitrans, over three consecutive years in two dairy farms located in semiarid climate in Aguascalientes State, in Mexico, were determined. The dairies were visited weekly between April 1999 to March 2002, on each occasion 10\% of the dairy cows were selected making direct counts of stable flies observed front the legs. The occurrence of stable fly adults from weekly counts was divided in four population phases: population increasing phase I (first peak), fluctuation phase, population increasing phase II (second peak) and population decreasing phase, for each year of study. Pearson's correlation analysis was developed $(P<0.01)$ between weekly average fly number per cow and mean temperature, mean relative humidity and rainfall recorded from one to four weeks before count in each population phases. The population increasing phase I, was observed in spring-summer period, in where relative humidity had significant correlation indices ( $r=0.6$ to 0.8), the first peak occurred in September, June and August, of each year studied, respectively. The population-decreasing phase was observed between last weeks of summer and in the fall, showed high correlation indices with temperature ( $r=$ 0.9). No significant correlations were founded with the rainfall over the study.
\end{abstract}

Key words: Stomoxys calcitrans, Seasonal distribution, Climatic factors, Dairy cattle.

\section{INTRODUCTION}

The stable fly, Stomoxys calcitrans (L.), is important and widely distributed pest of cattle in dairies and feedlots, in where found adequate conditions for breeding and develop immature stages $^{1,2}$; recently, has been reported as serious problem in range cattle ${ }^{3}$. Adverse effects may result from annoyance to cattle caused by large populations of adult flies associated with exsanguination and the possible transmission of various pathogens; the biting activity cause reduction on weight gain and milk production ${ }^{4}$.

The seasonal distribution of stable fly has been studied in several sites from North America, these studies found that seasonal distribution can be

\footnotetext{
* Instituto Tecnológico Agropecuario de Aguascalientes, AP 74-2, Admon. Postal No. 2, 20041, Aguascalientes, Ags. México.ccruz@itaa.edu.mx

** Cenid-Parasitología Veterinaria, AP 206, CIVAC, 62500, Jiutepec, Mor. México.

This study was supported by IFS Grant B/2588-1 and DGETA-SEP Grant.
} 
different according climatic conditions presents in each site and this information can be useful for understand the biology of the pest in each environment ${ }^{5}$. In Mexico, the epidemiology of stable fly has been scarce studied ${ }^{6,7}$, however is necessary more information about the infestation in field conditions for further applications in control strategies.

In the present study was determinate the influence of temperature, humidity and rainfall on field population trend of stable fly over three consecutive years in two dairy farms located in semiarid climate in Aguascalientes state, Mexico.

\section{MATERIALS AND METHODS}

The study was conducted in the dairy region from Aguascalientes State, located in the central part of Mexico. Its altitude $1885 \mathrm{~m}$ above sea level and has an historical annual precipitation of $475 \mathrm{~mm}$ with rainy season during summer and it has semiarid climate ${ }^{8}$.

Were included in the study two dairies (named "1" and "2"), located in San Francisco de los Romo county, these dairies maintain Holstein cows in confined conditions, referred to as "free confinement in open corrals", as were described previously ${ }^{7}$, and the owners acquire the compromise to not apply chemical treatment against biting flies during the study; the dairy " 1 " has 290 cows in milk production and dairy "2" has 350. The dairies were visited weekly from April 1999 to March 2002, in each occasion ten percent of the dairy cows were selected at random making a direct counts of adult flies front the legs; the counts were made the same day in both dairies between 12:00 to 15:00 hours by the senior author ${ }^{9,10}$.

The occurrence of stable fly adults from weekly counts was divided in four population phases: population increasing phase I (first peak), fluctuation phase, population increasing phase II (second peak) and population decreasing phase, for each year of study. Weekly average fly number per animal was correlated for each population phase, using Pearson's correlation coefficient ( $\mathrm{p}$ $<0.01$ ), with climatic parameters based on the data recorded at the meteorological station of San Francisco de los Romo county: weekly mean temperature, weekly mean relative humidity and weekly total rainfall. The analysis were developed using climatic values for $1,2,3$ or 4 weeks prior each count, for detect the influence of climatic factors in these time periods ${ }^{11,12}$. The SAS program $^{13}$, were used for analysis of data.

\section{RESULTS}

The correlation indices of high statistical significance between mean temperature, mean relative humidity and rainfall, in relation to the number of stable flies on Holstein cows in increasing or declining phases in three consecutive years is shown in Table 1, the population trend had the high correlation indices in the previous two weeks of counts.

The population increasing phase I, were observed in spring-summer period, in where relative humidity had significant correlation indices through the study ( $r=0.6$ to 0.8 ), the first peak

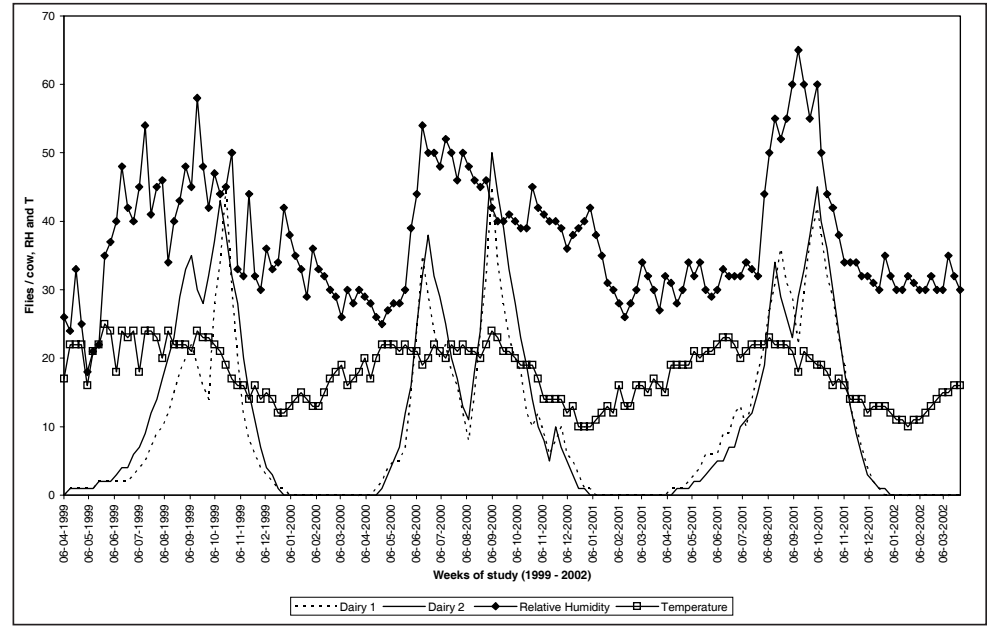

Figure 1. Seasonal distribution of $S$. calcitrans in relation to Relative Humidity (RH) and Temperature (T) in two dairies from Aguascalientes, Mexico. 
Table 1. Correlation coefficients (r) with high significance between temperature $(T)$, relative humidity (RH) and rainfall (Rf), and the average number of $S$. calcitrans flies per cow, in different population phases in two dairies from Aguascalientes, México, over three years

Population phases

$\mathbf{r}$

\begin{tabular}{lllllll} 
& & Dairy 1 & & & \multicolumn{3}{c}{ Dairy 2 } \\
& T & RH & Rf & T & RH & Rf \\
\hline First year1999-2000 & & & & & & \\
Increasing phase I (April - September) & $\mathrm{ns}$ & 0.607 & $\mathrm{~ns}$ & $\mathrm{~ns}$ & 0.824 & $\mathrm{~ns}$ \\
Fluctuation (September) & $\mathrm{ns}$ & $\mathrm{ns}$ & $\mathrm{ns}$ & $\mathrm{ns}$ & $\mathrm{ns}$ & $\mathrm{ns}$ \\
Increasing phase II (October) & $\mathrm{ns}$ & $\mathrm{ns}$ & $\mathrm{ns}$ & $\mathrm{ns}$ & $\mathrm{ns}$ & $\mathrm{ns}$ \\
Decrement (October - December) & 0.972 & $\mathrm{~ns}$ & $\mathrm{~ns}$ & 0.924 & $\mathrm{~ns}$ & $\mathrm{~ns}$ \\
& & & & & & \\
Second year 2000-2001 & & & & & & \\
Increasing phase I (April - June) & $\mathrm{ns}$ & 0.785 & $\mathrm{~ns}$ & $\mathrm{~ns}$ & 0.836 & $\mathrm{~ns}$ \\
Fluctuation (June - August) & $\mathrm{ns}$ & $\mathrm{ns}$ & $\mathrm{ns}$ & $\mathrm{ns}$ & $\mathrm{ns}$ & $\mathrm{ns}$ \\
Increasing phase II (August - September) & $\mathrm{ns}$ & $\mathrm{ns}$ & $\mathrm{ns}$ & $\mathrm{ns}$ & $\mathrm{ns}$ & $\mathrm{ns}$ \\
Decrement (September - December) & 0.964 & $\mathrm{~ns}$ & $\mathrm{~ns}$ & 0.937 & $\mathrm{~ns}$ & $\mathrm{~ns}$ \\
Third year 2001-2002 & & & & & & \\
Increasing phase I (April - August) & $\mathrm{ns}$ & 0.765 & $\mathrm{~ns}$ & $\mathrm{~ns}$ & 0.847 & $\mathrm{~ns}$ \\
Fluctuation (August - September) & $\mathrm{ns}$ & $\mathrm{ns}$ & $\mathrm{ns}$ & $\mathrm{ns}$ & $\mathrm{ns}$ & $\mathrm{ns}$ \\
Increasing phase II (September - October) & $\mathrm{ns}$ & $\mathrm{ns}$ & $\mathrm{ns}$ & $\mathrm{ns}$ & $\mathrm{ns}$ & $\mathrm{ns}$ \\
Decrement (October - December) & 0.922 & $\mathrm{~ns}$ & $\mathrm{~ns}$ & 0.923 & $\mathrm{~ns}$ & $\mathrm{~ns}$ \\
\hline
\end{tabular}

ns $=$ non- significant

Table 2. Climatological information from four seasons in the period 1999 to 2002: average temperature $\left(\mathbf{T}^{\circ} \mathrm{C}\right)$, average relative humidity $(\mathrm{RH} \%)$ and total rainfall $(\mathrm{Rf} \mathbf{~ m m})$

\begin{tabular}{lrrrrrrrrr}
\hline Season & \multicolumn{3}{c}{ Year 1 } & \multicolumn{3}{c}{ Year 2 } & \multicolumn{3}{c}{ Year 3 } \\
& \multicolumn{1}{c}{ T } & \multicolumn{1}{c}{ RH } & \multicolumn{1}{c}{ Rf } & \multicolumn{1}{c}{ T } & \multicolumn{1}{c}{ RH } & Rf & T & RH & \multicolumn{1}{c}{ Rf } \\
\hline Spring & 21.1 & 31 & 9 & 20.4 & 34 & 84.5 & 20.2 & 31.4 & 45 \\
Summer & 22.3 & 45.1 & 244.5 & 21.3 & 46.1 & 179 & 21.2 & 48.6 & 238.5 \\
Autumn & 16.8 & 38.5 & 0 & 14.9 & 40.3 & 47.5 & 15.1 & 38.6 & 80.5 \\
Winter & 15.1 & 32.5 & 0 & 13.7 & 31 & 28 & 12.9 & 30.7 & 18 \\
\hline
\end{tabular}

occurred in September, June and August, in each year studied, respectively (Figure 1). The population-decreasing phase was observed between last weeks of summer and in the fall, showed high correlation indices with temperature $(r=0.9)$. No significant correlations were founded with the rainfall over the study. The weather was typical for the region in reference to temperature, but not in the case of rainfall and relative humidity, the first year of study had less rain than second and third (Figure 1); the climatic factors recorded by season of year is shown in Table 2 .

\section{DISCUSSION}

The temperature, rainfall and humidity are the main climatic factors related with increase and decrease populations, however, the fly season can be different between localities and environment, as is reported in some studies ${ }^{9,14,15}$.

In the present study was found that relative humidity had a high correlation indices in the population increasing phase I (first peak), in despite to importance of temperature, which is responsible to emergence of adult flies from pupal 
overwinter at begin the fly season, in spring ${ }^{14,16}$. The population increase is slow at the beginning of the fly season and only has a fast growth when the humidity is more important due to seasonal rainfall. The first year of the study was dry with low rainfall in early summer and the peak was observed in September, in contrast in the second year the rainfall began in May and first peak occurred in June; in our study the relative humidity is the key to arrive to first peak.

In the fluctuation and population increasing phase II (second peak), was not possible detect any correlation between climatic factors and the population trend, may be due the homogenous weather conditions in the period (summer), an adequate combination between humidity and temperature, this situation has been reported in others studies?.

In the decreasing phase the temperature had a high correlation indices in all study $(\mathrm{r}=.90)$, his influence in the decrease population has been documented in the literature ${ }^{14}$; in the study region temperature decrease beginning in early October and in our study at same time decrease the population trend (Figure 1).

In the present study the relative humidity had an important influence in the population increasing phase I (first peak) and temperature had a definitive influence in the population decreasing phase; these observations can be an indicative to predict the behavior of the field stable fly trend in the study site and planning measures control, however more studies are necessaries to develop control strategies based in population models.

\section{RESUMEN}

El trabajo tuvo como objetivo determinar la influencia de la temperatura, humedad y la precipitación pluvial en la curva poblacional de campo de la mosca del establo, Stomoxys calcitrans, en un periodo de tres años en dos establos lecheros localizados en un clima semiárido en el estado de Aguascalientes, México. Los establos se visitaron semanalmente entre abril de 1999 y marzo del 2002, en cada ocasión se seleccionó al $10 \%$ de las vacas en lactancia realizando un conteo directo de moscas del establo que se observaran en el frente de las piernas. La ocurrencia de la mosca del establo en los conteos semanales fue dividido en cuatro fases: incremento poblacional fase I (primer pico), fase de fluctuación, incremento poblacional fase II (segundo pico) y fase de decremento poblacional, para cada año de estudio; se realizó un análisis de correlación de Pearson $(\mathrm{P}<0,01)$ entre el promedio semanal de moscas por vaca y la temperatura promedio, humedad relativa promedio y precipitación pluvial registradas de una a cuatro semanas antes del conteo, en cada una de las fases poblacionales. En el incremento poblacional fase I (primavera-verano), la humedad relativa fue el único factor climático con índices de correlación significativos $(\mathrm{r}=0,6$ a 0,8$)$, el primer pico ocurrió en septiembre, junio y agosto, respectivamente para cada año estudiado. La fase de decremento poblacional se observó en las últimas semanas del verano y en el otoño, detectando altos índices de correlación con la temperatura $(\mathrm{r}=0,9)$. No se encontró ningún coeficiente significativo con la precipitación pluvial en el estudio.

\section{REFERENCES}

1.- SCHMIDTMANN E T. Arthropod pests of dairy cattle, p. 223-38. In: Williams R E, Hall R D, Broce A B and Scholl P J (editors). Livestock Entomology. John Wiley \& Sons. New York, USA. 1985.

2.- SKODA S R, THOMAS G D, CAMPBELL J B. Developmental sites and relative abundance of immature stages of the stable fly (Diptera:Muscidae) in beef cattle feedlot pens in eastern Nebraska. J Econ Entomol 1991; 84: 191-7.

3.- CAMPBELL J B, SKODA S R, BERKEBILE D R, et al. Effects of stable flies (Diptera:Muscidae) on weight gains of grazing yearling cattle. J Econ Entomol 2001; 94: 780-3

4.- FOIL L D, HOGSETTE J A. Biology and control of tabanids, stable flies and horn flies. Rev Sci Tech Off Int Epiz 1994; 13: 1125-58.

5.- GREENE G L. Seasonal population trends of adult stable flies. Misc. Public. 74, Entomological Society of America, Lanham, MD. 1989.

6.- KUNZ S E. Epidemiology of the more important flies of cattle in Mexico. Proc 2th International Seminary Animal Parasitology. 1991. Oaxtepec, Morelos, México, p. 105-10.

7.- CRUZ-VÁZQUEZ C, MARTÍNEZ R S, VITELA M I, et al. Variación anual de la infestación por Stomoxys calcitrans (L.)(Diptera:Muscidae) en tres establos lecheros de Aguascalientes, México. Tec Pecu Mex 2000; 38: 135-42.

8.- CRUZ-VÁZQUEZ C, VITELA M I, RAMOS P M et al. Presencia de Haematobia irritans (L.) (Diptera: Muscidae) en ganado lechero estabulado de Aguascalientes, México: Informe preliminar. Vet Mex 1999; 30: 205-8.

9.- MULLENS B A, MEYER J A. Seasonal abundance of 
stable flies (Diptera:Muscidae) on California dairies. J Econ Entomol 1987; 80: 1039-43.

10.- THOMAS G D, BERRY I L, BERKEBILE D, SKODA S R. Comparison of three sampling methods for estimating adult stable fly (Diptera:Muscidae) populations. Environ Entomol 1989; 18: 513-20.

11.- GUGLIELMONE A A, ANZIANI O S, MANGOLD A $\mathrm{J}$ et al. Seasonal variation of Haematobia irritans (Diptera: Muscidae) in recently infested region of central Argentina. Bull Entomol Res 1997; 87: 55-9.

12.- BARROS A T M. Dynamics of Haematobia irritans (Diptera:Muscidae) infestation on nelore cattle in the Pantanal, Brazil. Mem Inst Oswaldo Cruz 2001; 96:
445-50.

13.- SAS INSTITUTE. SAS user's guide: statistics, version 6.0. SAS Institute, Cary, NC. USA. 1994.

14.- LYSYK T J. Seasonal abundance of stable flies and house flies (Diptera: Muscidae) in airies in Alberta, Canada. J Med Entomol 1993; 30: 888-95.

15.- GREENE G L, GUO Y J. Integrated stable fly (Stomoxys calcitrans) management in confined cattle feedlots. Recent Res Devel in Entomol 1997; 1: 243-50.

16.- KUNZ S E. The influence of temperature on adult and immature stable flies. In: Thomas G D, Skoda S R (editors). The stable fly: a pest of humans and domestic animals. University of Nebraska. Lincoln NE Agric Res Div Misc Public 1995; 64: 87-109. 